Luobbal Sámmol Sámmol Ánte (Ante Aikio)

Sámi University of Applied Sciences

\title{
Loanwords from unattested Nordic source forms in Saami ${ }^{1}$
}

Among the numerous loanwords Saami has adopted from Proto-Norse there are also cases where the loan original has not been retained in modern or historically attested Nordic languages. Such etymologies can nevertheless be established on the basis of surviving cognate forms in other Germanic languages. Seven previously proposed etymologies of this kind are scrutinized, including those for North Saami duodji 'handicraft' and ráidalas 'ladder'. Twelve new etymologies of the same type are argued for, among them explanations for the origin of North Saami ámadadju 'face', iktit 'reveal, disclose', and ivdni 'color'.

1. Previously known cases

2. New etymologies

As is well-known, the Saami languages possess a large number of old loanwords from Proto-Norse, the ancestral form of the Nordic (North Germanic) languages. While Proto-Norse is not strictly speaking a solely reconstructed language, being rudimentarily attested in Elder Futhark inscriptions, most of what is known about the language is nevertheless based on reconstruction through the comparative method. As the period of extensive attestation of Norse began only several centuries after the Proto-Norse period, it is quite obvious that Proto-Norse differed considerably from even the earliest attested forms of Old Norse. This is most evident in the realm of phonology, but it must also be true in regard to the language's lexicon.

1. A draft version of this paper was open for public commenting and discussion on the academic social networking site Academia.edu on 25 February - 19 March 2019. I wish to thank the participants Stephen P. B. Durnford, Onno Hovers, Adam Hyllested, Anthony Jacob, Petri Kallio, Martin Joachim Kümmel, Daniel Nikolić, Peter S. Piispanen, Juho Pystynen, Johan Schalin, George Telezhko, Rémy Viredaz, and Mikhail Zhivlov for helpful comments and suggestions. 
A productive avenue of loanword research is opened by the assumption that Proto-Norse had preserved lexical archaisms of Proto-Germanic ancestry, which later became lost in the Nordic languages prior to their attestation. Thus, it is conceivable that Saami has adopted some Nordic words which are not found in the attested Nordic languages at all, but which have been preserved in their more southern Germanic sister languages. Indeed, in earlier research a couple of such borrowings have been proposed. In this brief paper I will present some additional remarks on seven etymologies of this type that have been put forward by earlier research, as well as present twelve new etymological comparisons of the same type.

\section{Previously known cases}

I.I. SaaU duöjjie, SaaP SaaL duodje 'handicraft', SaaN duodji 'handicraft; finished product', SaaI tyeji 'handicraft; product; deed', SaaSk tuâjj, SaaK $t \bar{u} j j$, SaaT tījje '(manual) work; handicraft' (< PSaa *tuojē)

$<$ PNo *tōja-

Qvigstad (1893: 139) explains this word as a loan from an unattested ONo *tói, the assumed cognate of Goth taui (: GEN tojis) 'deed, act'. The etymology is indeed obvious, but there is no reason to postulate a specifically Old Norse source form; the Saami word is more likely to stem from an even older (Proto-)Norse form *tōja-. An early date of borrowing is suggested by attestation in the easternmost Kola Saami languages, and especially by the fact that no cognates of Goth taui are attested either in Norse or in West Germanic. As the word is a basic vocabulary item, it was thus probably lost already prior to extensive attestation of Norse and West Germanic as literary languages. It is certain, at any rate, that the Gothic taui is a lexical archaism: it reflects PrePGerm ${ }^{\star}$ dōw-jo- and shows a regular loss of ${ }^{*} \mathrm{w}$ after ${ }^{{ }^{\circ}} \mathrm{o}$ in Proto-Germanic; ${ }^{*}$ tō- $<{ }^{*}$ dōw- represents the full grade of a root that is also found in PGerm *tauja- $>$ Goth taujan 'do, make'; the latter form shows a different grade with a short vowel, which allowed the glide to be preserved (Kroonen 2013: 511, 520).

It can be noted that there is another derivative in Norse that contains the full-grade root *tō-, namely ONo Icel Far tól 'tool' ( $<$ PGerm *tōla, cognate with OEngl tōl 'tool' $>$ Engl tool). According to Kroonen (2013: 520) it developed regularly from earlier ${ }^{*}$ tôlla- $<{ }^{*}$ tō-dla-, formed with the deverbal instrument noun suffix ${ }^{*}$-dla- $\left(<^{*}\right.$-d $\left.\mathrm{d}^{\mathrm{h}} \mathrm{lo}-\right)$. It has not been previously noticed that also *tōla- was borrowed into Saami: it must be the source of 
SaaSk tue'll, SaaK tūlll, SaaT tîllle 'plane (the tool)' (< PSaa *tuolē). The etymology presupposes a semantic narrowing from 'tool' to a particular basic tool ('plane'), but such an unremarkable shift of meaning hardly poses a problem. Moreover, this explanation is in any case more straightforward than the previously suggested comparison to SaaL duollat 'steady (of a boat); straight (of ski, tree, etc.)', SaaN duollat 'steady (of a boat or sledge)' (Itkonen 1958: 616). The Norse origin of the word is also corroborated by the fact that also several other Saami words for basic tools are Norse loans, e.g. SaaN ákšu 'ax', niibi 'knife', filu 'file', liššá 'scythe', nábár 'auger' (cf. ONo øx 'ax', knifr 'knife', OSw fäl, ONo (hapax) fél 'file', lé 'scythe', nafarr 'auger').

I.2. SaaU fiärruot, SaaP SaaL fierrot, SaaN fierrut 'stir (continuously or repeatedly)' (< PSaa *fierō-), SaaN fir'ret 'stir (momentarily)', SaaI vierriđ, SaaK vīr.šed 'stir' (< PSaa *fierešes- *vierešes-)

$<$ PNo * pvera-

Qvigstad (1893: 150) postulates an unattested ONo noun ${ }^{\star} p$ vera corresponding to modern Icelandic pvara 'stick for stirring food in a cauldron'. In this form the etymology is obviously erroneous, as also in Old Norse the form of this noun was pvara, not ${ }^{*}$ pvera. Instead, the source form must have been an etymologically related verb with a different ablaut grade: PNo *bvera- 'stir'. It is not certain whether this verb has survived in Norse, but at least corresponding forms are found in West Germanic: OHGerm dweran, OEngl pweran 'stir'. Adam Hyllested points out in the Academia.edu discussion session that Danish tvoere 'stir' could in principle continue the verb *bvera-, although this is uncertain as it could also be a denominal verb derived from the noun $p v a r a$. At any rate, a deverbal noun derived from this verb is preserved in Norse: ONo Icel byrill 'beater, whisk' ( OEngl pwirel, OHGerm thwiril) < ${ }^{*}$ pwerila-z (Kroonen 2013: 555).

I.3. SaaN fiidnu 'stack of firewood' (< PSaa ${ }^{\star}$ fijnō), SaaL svijnno 'stack of firewood' (<PSaa ${ }^{\star}$ svijnō)

$<$ PNo ${ }^{\star}$ fīnō-

SKES (s.v. pino) explains the Saami word as a loan from PNo ${ }^{\star}$ fīnō-. Corresponding forms are found in West Germanic: OEngl fin 'heap, pile', wudu-fin 'stack of firewood', OHGerm witu-fina 'stack of firewood' (wudu, witu 'wood'). As regards SaaN fiidnu, the etymology is both phonologically 
and semantically impeccable. SaaL svijnno does feature an unexpected initial cluster $s v$-instead of $f$-, but even this feature has a well-established parallel in SaaL sváles 'whale' < PSaa *svālēs, which is in turn from PNo ${ }^{\star} h^{w}$ alaz (> ONo hvalr 'whale'); cf. the expected initial $f$-in SaaS faala, SaaN fális 'whale' (< PSaa ^fālēs). A word further worth noting in connection with this etymology is Fi pino 'stack', a separate borrowing from Germanic *finō- (LÄGLOS II s.v. pino); the Finnish word has also been further borrowed into Saami, cf. SaaI pino 'stack'.

\section{I.4. SaaS gealoe 'throat (of a reindeer)' $\left(<\right.$ PSaa ${ }^{*}$ kielō) $<$ PNo *kelōn-}

Koivulehto (1992: 91-92) has explained the word as a loan from PNo *kelōn-, corresponding to attested forms in West Germanic: OHGerm kela (> Germ Kehle), Du keel, OEngl ceole 'throat'. To this completely straightforward etymology one only needs to add that the word might not be completely unattested in Nordic after all: Kroonen (2013: 184) notes that the Elfdalian bird name grạ-tjyölu 'Eurasian siskin' could be etymologically interpreted as "firtree-throat", suggesting the existence of an unattested ONo noun ${ }^{*} k j a l a: \mathrm{OBL}^{*} k j g l u$ 'throat'. And in any case the Nordic languages retained a derivative based on *kelōn-, namely the noun *kelkan- > ONo kjalki 'jaw; sledge', Far kjálki 'cheekbone' ( OHGerm kelah 'goiter'; Kroonen 2013: 184).

I.5. SaaS raajreles $\sim$ raajteres, SaaU rájddaris, SaaP rájdaris, SaaL ájdaris,

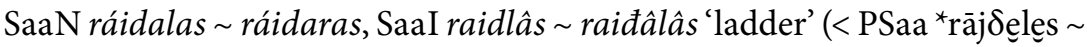

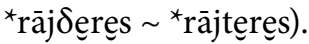

$<$ PNo ${ }^{\star}$ hlaidraz

These Saami words for 'ladder' show extensive phonological variation. The

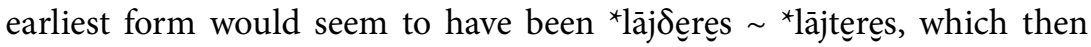

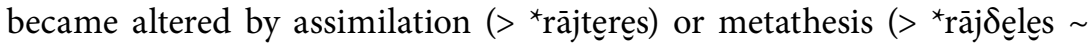
${ }^{\star}$ räjteles). The loss of the initial consonant in the SaaL variant ájdaris is difficult to account for; perhaps it derives from the assimilated variant ${ }^{*}$ rājteres via a subsequent dissimilatory loss of the first ${ }^{*}$ r. In any case, the

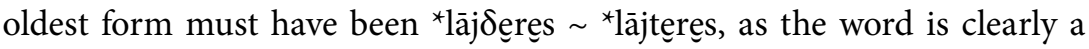
Nordic loan: its source must have been PNo *hlaidraz 'ladder', a noun not preserved in Norse but found in West Germanic, cf. OHGerm leitara (> Germ Leiter), OEngl hlēeder 'ladder' (> Engl ladder). Qvigstad (1893: 254) 
suggested that the Saami forms were borrowed from an unattested ONo ${ }^{\star}$ leiðar. However, the expected ONo reflex would actually be ${ }^{\star} h l e i ð r$, and moreover, the Saami forms point to a Proto-Norse level of phonological development. Qvigstad also mentioned Estonian redel 'ladder' in this connection, but this is an etymologically unrelated word: it was borrowed from Baltic German Reddel Rettel 'manger; ladder' (EES s.v. redel).

\subsection{SaaN ruohtti, SaaI ryetti 'soot' (< PSaa *ruottē) \\ $<$ PNo ${ }^{\star}$ hrōta-}

Koivulehto (2003: 298) explained SaaN ruohtti 'soot' as a Germanic loan; the source form can be identified as PNo *hrōta-, the unattested cognate of OHGerm ruoz (> Germ ruß), OSax hrōt 'soot', MDu roet 'grease, soot' ( $>$ Du roet 'soot'). The origin of the Germanic word remains unknown (Kroonen 2013: 249), but the Saami form shows that it must have once occurred in Norse, too. The distribution of the word is limited to North and Inari Saami, but despite this the borrowing is probably quite old, considering that no trace of the word survives in Norse. The loan etymology is both phonologically and semantically completely transparent, and as such requires no further comment.

I.7. SaaL sjtádtjo 'frying pan; casting ladle (for lead)', SaaN stážžu 'crucible (for melting lead); iron ashtray under a stove’ (<PSaa *stāńćō)

$<\mathrm{PNo}^{*}$ stainjō- ${ }^{2}$

As originally proposed by Wiklund (1912:30-32), the source of the Saami word must have been $\mathrm{PNo}{ }^{*}$ stainjō-, the unattested cognate of OHGerm steina, OEngl stäna 'stone or earthenware pot' (> Engl dial. stean, stean-pot 'earthenware pot'). The word was derived from the noun *staina- 'stone', and thus it must have originally designated a 'stone pot'. The Saami word shows

2. In PNo reconstructions I have chosen not to indicate the effects of Sievers's Law, i.e. the vocalization of ${ }^{*}$-j- after so-called 'heavy syllables', a sound change or morphophonological process which many scholars assume to be of ProtoGermanic or even Proto-Indo-European ancestry. The reason for this is that the Saami languages possess several old Nordic or Germanic loanwords which appear to point to the absence of Sievers's Law in the donor language, one example being the word *stāńćo discussed here. However, the details of this issue call for a more thorough analysis that is beyond the scope of the present paper. 
the substitution of the affricate *c for PNo postconsonantal ${ }^{*}$; t this rule has many well-established parallels, e.g. SaaN skálžu 'seashell' (<PSaa ${ }^{\star}$ skālćō) $<$ PNo *skaljō- (> ONo skel) and SaaN ávža 'bird-cherry' (< PSaa *āvćé) $<$ PNo ${ }^{\star}$ hagja- $(>$ ONo hegg). The phonological and phonetic motivation of this substitution pattern has, however, not been explained so far.

It should be noted that in South Saami there is a similar noun haadtjoe

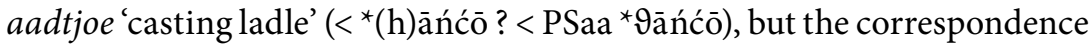
of initial $h$ - or $\varnothing$ - to the cluster st-in Lule and North Saami is completely anomalous. It is not clear how this form should be explained, and one certainly cannot exclude the possibility that it is a word of different origin that has become somehow contaminated with the Norse borrowing *stānćō. Wiklund (1912: 32) proposed that it is a borrowing from a Germanic parallel form * painjō-, which in his view represents a case of archaic alteration between initial ${ }^{\star}$ st- and ${ }^{*} t-\left({ }^{*} \mathrm{p}-\right)$. Because such a form is not attested anywhere in Germanic, this is an ad hoc speculation, however.

\section{New etymologies}

\section{I. SaaS aajtoe 'large fire' (< PSaa *ājtō) \\ $<\mathrm{PNo}$ *aida-}

The loan original *aida- has no direct reflex in Nordic, but it is well attested in West Germanic: OEngl $\bar{a} d$ 'pyre', OFri āde, OHGerm eit 'fireplace, pyre' ( $<$ PGerm *aida-). Moreover, even Nordic preserves an obscured trace of this root: ONo eldr 'fire' ( OEngl äled 'fire') goes back to PGerm *ailida-, a derivative of the verb *ailja- (> OEngl celan 'set on fire; burn'), which in turn was derived from the noun *aila- (> OEngl a $l$ 'fire'). PGerm *aila- goes back to earlier *aid-la-, and is thus ultimately a derivative of PGerm *aida(Kroonen 2013: 11). Moreover, West Germanic *aida- is in any case of ProtoIndo-European origin because it is cognate with Sanskrit édha- 'firewood', Ancient Greek aĩ $90 \varsigma$ 'firebrand', and Old Irish áed 'fire' ( $\left.<\mathrm{PIE}{ }^{\star} \mathrm{h}_{2} \mathrm{aid}^{\mathrm{h}} \mathrm{O}-\right)$.

The loan etymology is both semantically and phonologically straightforward. Remarkably, there is a phonological feature pointing to quite early borrowing: PSaa ${ }^{*} t$ as the substitute for PNo intervocalic ${ }^{*}$ d. This suggests that the sound in the source form was still phonetically realized as a voiced stop and had not undergone spirantization $\left({ }^{*} \mathrm{~d}>[ð]\right)$. In most loanwords, PSaa ${ }^{\star} \delta$ appears in place of PNo ${ }^{\star} \mathrm{d}$ in intervocalic position: cf. for example

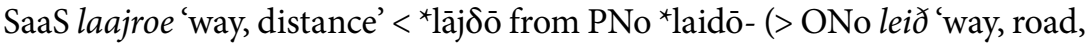




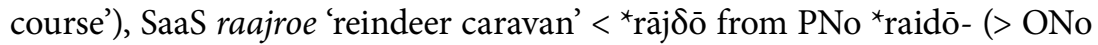
reið 'riding; vehicle'). Thus, if SaaS aajtoe 'large fire' had been borrowed from the same (Proto-)Norse language variety as laajroe and raajroe, we would instead expect it to have the form ${ }^{\star}$ aajroe $\left(<\mathrm{PSaa}{ }^{\star} \bar{a} j \delta \bar{o}\right)$. Instead, it seems to derive from an older, more archaic Norse variety with intervocalic voiced stops.

Apparently, only one other loanword showing PSaa ${ }^{*}$ in place of PNo intervocalic ${ }^{*} \mathrm{~d}$ has been established by previous research: SaaN ruohtu 'primitive fence made of branches and the like' (<PSaa ${ }^{\star}$ ruotō). This word must have been borrowed either from PNo ${ }^{\star}$ trōdō- $\sim{ }^{\star}$ trōdōn- (> ONo tróð 'rafter', tróða 'pole, board', OSw trō $p$ 'fence' > Sw dial. trod 'fence, fence pole, rafter', troda 'pole, fishing rod'), as has been suggested by Qvigstad (1893: 277), or alternatively from PNo *rōdō- *rōdōn- (> ONo róða 'pole, cross', Sw dial. rod'fence pole'). Regardless of which etymology is the correct one, it must be concluded that in this loanword the Saami stop ${ }^{*} t$ was substituted for PNo intervocalic ${ }^{*}$ d. One should note that in this connection Qvigstad also lists other Saami forms, e.g. obsolete Lule Saami ruodo, truodo 'rod, stick' and North Saami (extinct West Sea Saami dialects) truodza 'fishing rod', truođdi, ruođdi 'rafter', which cannot be directly etymologically related. Because their intervocalic consonants (SaaL $d$, SaaN $d d$ ) point to an original spirant ${ }^{\star} \delta$, they must be separate, more recent borrowings from ONo tró $\partial$, tróða. Moreover, the variation in meaning and the occurrence of several phonological variants with different second-syllable vowels suggest that these forms represent at least three parallel borrowings.

One can also present another new etymology that displays the consonant correspondence Saami ${ }^{\star} t \sim$ PNo ${ }^{\star} d$ in intervocalic position. The origin of the following set of derivationally related Saami verbs has not been previously explained:

- SaaS ruhtedh 'take by force, rob', SaaSk råå'tted, SaaK rodde $\delta$ 'tear at, yank, tug' (<PSaa ${ }^{\star}$ rotēe-).

- SaaU ruhttuot, SaaL råhtot, SaaSk rååttad, SaaT rottad 'tear at, yank, tug' (< PSaa *rotō-).

- SaaU rühttet, SaaL råhttit, SaaN rohttet, SaaI ruttiđ, SaaSk ro'ttjed, SaaK rodd.jed, SaaT rotțid 'yank, tug (once)' (<PSaa ${ }^{\star}$ roteje- $)^{3}$.

3. In SaaK forms such as rodd.je $\delta$, the dot (.) is used to indicate a historically lost vocalic nucleus of what can be synchronically described as a "degenerate syllable" consisting of a mere consonantal onset followed by an overshort vowel which 
This set of verbs must ultimately stem from either PNo ${ }^{\star}$ rudja- (> ONo ryðja 'clear, empty; clear land (from trees)') or the etymologically related PNo *rudō-. The latter verb is not preserved in Norse, but cognates in West Germanic are well attested: MDu roden 'clear' ( $>$ Du rooien 'pull out, clear (land)'), MHGerm roten 'clear' (> Germ aus-rotten 'exterminate') (Kroonen 2013: 416). Germ roden 'clear (land of trees)' also belongs in this cognate set, but its $-d$ - reveals that it was adopted from Low German varieties.

It is somewhat difficult to determine whether the exact source of borrowing was PNo ${ }^{\star}$ rudja- or ${ }^{\star}$ rudō-, or even both. In purely phonological terms, the former could have straightforwardly produced PSaa ${ }^{\star}$ roteje- 'yank, tug (once)', and the latter in turn PSaa *rotō- 'tear at, yank, tug (repeatedly)'. However, there is a fully regular derivational relationship between these two Saami verbs: verb pairs with the suffixes ${ }^{*}$-eje- for punctual aspect and ${ }^{*}-\overline{0}-$ for iterative-continuative aspect are very frequent in the Saami languages, and the derivational pattern is even synchronically at least somewhat productive. Then again, there is also the PSaa variant ${ }^{*}$ rotē- with no overt derivational suffix, and it could represent the historically primary form from which ${ }^{\star}$ roteje- and ${ }^{\star}$ rotō- were derived within Saami. In that case, the source of borrowing would have been PNo ${ }^{\star}$ rudō- rather than ${ }^{\star}$ rudja-.

2.2. SaaL ámadadjo 'appearance, character', SaaN ámadadju 'face' $\left(<\right.$ PSaa ${ }^{* a ̄ m e}(n)$ tejōo $)$

$<$ PNo *hamepja-

This Saami word displays a very unusual phonological structure: a quadrisyllabic root that nevertheless contains no identifiable derivational suffix. As the word cannot be explained as an obscured compound either, this feature in itself suggests loan origin. A potential loan original is provided by $\mathrm{PNo}$ *hamepja-, which can be postulated on the basis of West Germanic forms: OHGerm hemidi 'shirt, garment' (> Germ Hemd), OSax hemithi 'shirt', OEngl hemepe 'undergarment with short sleeves, shirt'.

There is a notable semantic difference between the Saami and Germanic forms. However, one can hypothesize that the loan original referred not only to 'shirt' but also to 'skin', 'appearance', or the like, because PGerm *hamepja- is a derivative of PGerm *hamaz > ONo hamr 'skin, slough,

does not appear to be an independent phonological segment (see Sammallahti 2012). Thus, the mentioned form has not two but three syllables (rod-d-je $\delta$ ). 
shape, form' (> Far hamur 'skin, slough; ghost, apparition', Icel hamur 'skin'), OHGerm hamo 'wrapping, garment', OEngl hama 'covering'. The word *hamaz has been borrowed into Finnic as *hameh (> Finnish hame 'skirt'). SaaN hápmi 'shape, figure' and hápma 'skin (of a skinned animal); disguise', in turn, are more recent borrowings from Norse.

The etymology is phonologically quite straightforward, except for a small glitch: the single nasal $-m$ - in SaaL and SaaN represents the weak grade of consonant gradation, and it would thus seem to suggest the presence of an original cluster $\left({ }^{*}\right.$-nt-?) on the border of the second and third syllables. The form ^āmetejō would predictably have yielded SaaL *ábmadadjo, SaaN *ápmadadju, whereas the reconstruction *āmentejō would account for the attested forms. Perhaps however the weak grade is a later irregular development. It is also possible that the form *āmentejō developed from earlier *āmetejō by influence of another phonologically close word with the same meaning: SaaS ååredoejja, SaaU árruodahkka, SaaL árudidja 'face' < PSaa *āruntej V *ārōnteke. This word, too, has lacked an etymology so far, but it is obviously a borrowing from $\mathrm{PNo}$ *harunda/ō- > ONo horund 'human flesh; skin, complexion' (see Kroonen 2013: 213). But whatever the background of the weak grade in SaaL ámadadjo and SaaN ámadadju is, the phonological discrepancy between the Saami and Norse forms is in any case so small that it can hardly be seen as a serious obstacle to the loan etymology, especially considering that the anomalous phonotactic structure of the Saami noun indicates that it must be a loanword. It is worth noting that Saami noun roots ending in *ejō are generally Nordic borrowings; compare the following examples:

- SaaN gáldu, SaaI käldee ‘spring (of water)’ < kāltejō from PNo *kaldjōn(> ONo kelda 'spring').

- SaaN hárdu, SaaI ärdee 'shoulder' < ${ }^{*}(\mathrm{~h})$ ārtejō from PNo *hardjō(> ONo herðar PL 'shoulders').

- SaaN rádnu, SaaI rännee 'animals tracks in snow' < ${ }^{\star}$ rānnejōō from PNo *rannjōn- (> ONo renna 'running, course’).

- SaaL hilldo, SaaN hildu ildu, SaaI ildee, SaaSk i'lddi 'shelf' < (h)iltejō from PNo *hilpjōn- (> Icel hilla, Far hill 'shelf'). Note also the variant with differing vocalism: PNo *hulpjōn- ( $>$ Sw hylla, Nw hylle 'shelf').

- SaaS dytneje, SaaP SaaL diddno, SaaN didnu 'flint' < *tinnejō from PNo *tinnjōn- (> ONo tinna 'flint'). Note that SaaI tinno, SaaSk tenn, SaaK tinn 'flint' must be borrowings from North Saami: by regular phonological development, PSaa *tinnejō would have produced the non-existent forms SaaI ${ }^{\star}$ tinnee, SaaSk ${ }^{\star}$ ti'nni, SaaK ${ }^{\star}$ tin̄nnej. 
- SaaS raavnije, SaaP SaaL rávnno (GEN rávno) 'rowan' < ${ }^{*}$ rāvnejōō (? *rāvnō) from PNo ${ }^{\star}$ raunjō- (> ONo reynir). The SaaP and SaaL forms may have analogically acquired consonant gradation, which is characteristic of originally bisyllabic nouns. Alternatively, PNo ${ }^{*}$ raunjō- may have been separately borrowed as bisyllabic *ā̄vnō into the predecessor of Pite and Lule Saami.

2.3. SaaL buttas 'decorative band sewn on the edge of a piece of clothing' (< PSaa * puntes)

$<$ PNo ${ }^{\star}$ bundaz

The noun * puntes is only attested in Lule Saami, but it must originally have had a wider distribution, as it is the derivative base of a very widely attested verb: SaaS budtedh, SaaU büddet, SaaP SaaL buddit, SaaN buddet, SaaI puddid 'sew a decorative band on the edge of a piece of clothing', SaaSk pu'ddjed, SaaK puñd.je $\delta$ 'darn, repair by stitching' (< PSaa *punteje-). The noun can be phonologically flawlessly explained as a loan from PNo *bundaz, the unattested cognate of MHGerm bunt 'ribbon, band, fetter' (> Germ Bund 'bond, alliance, association; waistband'), MSax bunt 'bond, alliance, agreement', Du bond 'society, union, alliance, league' (Kroonen 2013: 84). Also the semantic correspondence is completely straightforward: the general meaning 'ribbon, band' is found in Middle High German, and the Saami word refers to a specific type of ribbon or band used for decorative edging on clothes. The Germanic noun is also the derivational base of the diminutive *bundilō- > Germ Bündel, MDu bundel, OEngl byndele 'bundle' (note that Engl bundle does not continue OEngl byndele, but was instead borrowed from $\mathrm{MDu}$ bundel). Originally, PGerm *bundaz is a zero-grade derivative of the verb *binda- 'bind'.

\subsection{SaaU dualgguo, SaaL duolggo, SaaN duolgu 'bribe' (< PSaa *tuolkō) $<$ West Norse ${ }^{\star}$ dolga- $\left(<\mathrm{PNo}^{\star}\right.$ dulga- $)$}

The Saami word has been compared to Fi talkoot (plurale tantum) 'volunteer group work, gathering for volunteer work', which is a Baltic loanword, cf. Lithuanian talkà, Latvian talka 'volunteer work, group of volunteer workers, feast organized for volunteer workers' (SSA s.v. talkoo). However, the assumed semantic development to 'bribe' in Saami appears rather farfetched, and there is thus reason to look for another etymology. 
Gothic ${ }^{\star}$ dulgs (GEN dulgis) 'debt' ( ${ }^{\star}$ dulga-) comes formally and semantically close to the Saami word. Assuming that the word also once occurred in Norse, it would have regularly undergone the lowering of ${ }^{*} \mathrm{u}$ to ${ }^{*} \mathrm{O}$ and thus developed into *dolga- in the West Norse area. Such a form suits perfectly as the loan original of Saami ${ }^{\star}$ tuolkō. Indeed, we can find a parallel which must reflect this vowel lowering, as it shows the PSaa diphthong ${ }^{\star}$ uo in place of West Norse ${ }^{{ }} \mathrm{o}<{ }^{*} \mathrm{u}$ : cf. for example SaaN guolbi 'earth floor' $(<$ PSaa ${ }^{\star}$ kuolpē), which was borrowed from West Norse *golba- $>$ ONo golf 'floor' (cf. Kroonen 2013: 194). As regards semantics, the development from 'debt' to 'bribe' is easy to understand and the two concepts are quite close: both involve a payment made in order to satisfy the requirements of another party.

It is not a problem for the etymology that attestations of the Germanic word are limited to Gothic. The word appears to be old in any case: it can be analyzed as a reflex of Pre-PGerm ${ }^{*} \mathrm{~d}^{\mathrm{h}} \mathrm{g}^{\mathrm{h}}-\mathrm{o}-$ and cognate with Slavic *dъlgъ (> Old Church Slavonic dløgz, Russian долг, Czech dluh, Bulgarian dălg, etc. 'debt'). The Slavic word has also been argued to be a Germanic loanword (Pronk-Tiethoff 2012: 142), but even if this is the case, Old Irish dligid 'owe, be entitled to' and dliged 'duty' are still left as cognates of the Gothic word (Derksen 2008: 129-130; Kroonen 2013: 108). There is also a formally identical word in Norse and West Germanic: ONo dolg 'enmity', OHGerm tolg, OEngl dolg 'wound' ( $<{ }^{\star}$ dulga-). Due to the semantic difference this is probably of different origin, however: the Slavic cognates point to 'debt' as an archaic meaning, from which it is difficult to derive the concrete meaning of 'wound' (cf. de Vries 1977: 78-79; Kroonen 2013: 108).

2.5. SaaS gaalve, SaaU gálvva, SaaL gálvva, SaaN gálva, SaaI kalvâ, SaaSk kalvv, SaaK $k \bar{\alpha} \bar{l} v$ 'dead and dry tree which has lost its bark (mostly of deciduous trees)' (< PSaa ${ }^{\star} k a ̄ l v e$ )

$<$ PNo *kalwa-

The Saami noun can be derived from an unattested PNo adjective *kalwa-, which has cognates in West Germanic: OEngl calo 'bald' (> Engl callow), OHGerm kalo 'bald' (> Germ kahl 'bald; leafless'). The word is of PreProto-Germanic origin and related to Old Church Slavonic golo 'naked', glava 'head' and Lithuanian galvà 'head' (Kroonen 2013: 278). The basic meaning of the Germanic adjective is 'bald', but it is noteworthy that in several modern Germanic languages the word also has the secondary metaphorical meaning 'leafless'; this is true at least of German kahl, 
Swedish kal (which was borrowed from Middle Saxon) and Dutch kaal. This bridges the semantic gap between the Saami and Germanic forms. Thus, the semantic development of the Saami word was motivated by a metaphoric expression: the lack of leaves (or, perhaps, the lack of bark) on a dead and dried deciduous tree was likened to 'baldness'.

2.6. SaaL iktet, SaaN iktit, SaaI ihted 'reveal (something secret), disclose' $\left(<\right.$ PSaa ${ }^{*}$ iktē-)

$<$ PNo ${ }^{*}$ ihtja-

The Saami verb *iktē- has no known established etymology. In his dictionary, Nielsen (1979 s.v. $i k$ 'tet) regards SaaN iktit a derivative of the verb ihtit 'appear, come in sight' ( $<$ PSaa ${ }^{*}$ itē-). However, these two verbs do not stand in a regular relationship to one another: there is simply no morphological process in Saami by which ${ }^{\star} i k t e \bar{e}$ - could have been derived from ${ }^{\star}$ itēe. Despite their similar meanings the two verbs show no real correspondence beyond their initial vowel ${ }^{*} i$, and hence they cannot have a true etymological connection.

A phonologically suitable Norse loan original for Saami ${ }^{\star}$ iktē- can be reconstructed: PNo ${ }^{*}$ ihtja- is the predictable reflex of PGerm ${ }^{*}$ jehtja-, attested in OHGerm jihten 'witness, confess, give a testimony, let decide', OFri jechta 'confess, convict'. The verb is derived from the noun *jehti- > OHGerm jiht 'confession; praise', OFri jecht 'confession' (EWbAhd 5: 292-294). Semantically the comparison is very close: the uniting factor is the reference to a speech act disclosing or revealing some kind of misdeed, either one's own ('confessing') or that performed by another ('witnessing'). There is no phonological obstacle to the etymology either, as long as it is assumed that the borrowing took place before the assimilation of ${ }^{*} h t$ to $t t$ in Norse. There are several other loans showing the same sound substitution $\mathrm{PNo}{ }^{\star} \mathrm{ht}>\mathrm{PSaa}{ }^{\star} \mathrm{kt}$ :

- SaaS rïekte 'straight', SaaN riekta 'right, correct' < ${ }^{\star}$ riekte $<\mathrm{PNo}{ }^{\star}$ rehti(> ONo réttr 'straight, upright, right').

- SaaS raaktse 'trace (on a reindeer harness, for pulling a sled)' < ${ }^{*}$ rākce $<{ }^{\star}$ rāktẹs $<$ PNo ${ }^{\star}$ drahtu-z ( $>$ ONo dráttr 'pulling; hesitation').

- SaaU suktta 'cold (illness)' < ${ }^{\star}$ sukte $<$ PNo *suhti- (> ONo sótt 'illness').

- SaaL diktet 'make watertight' < *tiktē-, SaaL divtes (PL diktása), SaaN divttis (PL diktásat) 'watertight' < *tiktēs: *tiktāse- $<$ PNo * pĩhtja(pinhtja-) (> ONo pétta 'make watertight'), ${ }^{\star}$ pĩhtu-z ( ${ }^{\star}$ pinhtu-z) (> ONo péttr 'watertight'). Due to semantic and chronological reasons, 
it is unlikely that these Saami words derive from Sw dikt ADJ 'powerful, emphatic, skilled' (obsolete), dikt ADV 'tightly', which were borrowed from MSax dicht, cognate with ONo péttr. Note furthermore that SaaN deahtis 'watertight, close, dense' ( $<{ }^{*}$ teattēs) is evidently a later loan from ONo péttr, postdating the change ${ }^{*} \mathrm{ht}>{ }^{*} \mathrm{tt}$. These etymologies stem from Qvigstad (1893: 132-133), who however failed to notice that two separate borrowings of different ages are involved.

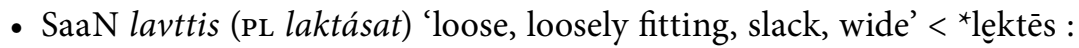
${ }^{*}$ lẹktāsẹ- < PNo *līhta-z ( ${ }^{*}$ linhta-z) (> ONo léttr 'light (not heavy); easy, unencumbered; nimble, active'). This is a new etymology. The development of PSaa ${ }^{*}$ from earlier ${ }^{*} i$ has also occurred in some other early borrowings: e.g. SaaN lađas 'joint' < ${ }^{\star}$ legess < PNo ${ }^{\star}$ lipu-z (> ONo liðr 'joint'); SaaN mas'sit 'lose (irretrievably)' $<{ }^{*}$ messē- $<$ PNo ${ }^{*}$ missja(> ONo missa 'miss, lose'); SaaN vahkku 'week' < *vekkō < PNo ${ }^{\star}$ wikōn- (> ONo vika 'week'); SaaL slahpa 'rock ledge, inward sloping cliff' < ${ }^{\star}$ slepe $<$ PNo ${ }^{\star}$ kliba- (> ONo klif'cliff').

- SaaS naaktse 'the dark of night' < ${ }^{\star}$ nākce $<$ (?) ${ }^{\star}$ nāktẹ(-)s $<$ PNo ${ }^{\star}$ naht-(s) ( $>$ ONo nátt, nótt 'night'). This is a new etymology. The form ${ }^{\star}$ nākce with its cluster ${ }^{\star} \mathrm{kc}=[\mathrm{kts}]$ was probably analogically extracted from a syncopated oblique stem (PSaa ${ }^{\star}$ nāktess : ${ }^{\star}$ nākcẹ-, from earlier ${ }^{*}$ nāktes : ${ }^{*}$ nāktesse-). However, one cannot completely exclude the possibility that it was directly borrowed from a NOM.SG ${ }^{*}$ naht-s prior to the loss of the final sibilant after a consonant stem in Norse (cf. Gothic NOM.SG naht-s 'night', with the sibilant retained).

- SaaS dektier, daktere 'married daughter' < *toktēr : *toktārẹ- < PNo *duhter- ( $>$ ONo dóttir 'daughter'). The Saami word has been previously considered cognate with Finnish tytär (GEN tyttären) 'daughter', which is of Baltic origin (cf. Lithuanian duktẽ 'daughter') (SSA s.v. tytär). However, the consonant correspondence between the Finnish and Saami words is irregular, so it is more probable that Saami has separately borrowed the word from Nordic.

2.7. SaaL irás, SaaN iras, hiras, SaaI SaaSk iirâs, SaaK ịras 'timid, skittish (of animals)' (< PSaa *ires)

$<$ Early Norse ?*irriar $\left(<\mathrm{PNo}{ }^{*}\right.$ irzjaz $<{ }^{*}$ erzjaz)

The proto-form of the Saami adjective can be reconstructed as ${ }^{*}$ ires. The initial $h$-in the North Saami variant hiras must be a secondary hypercorrect 
addition; the same phenomenon is attested in a couple of other words as well, e.g. SaaN haksit SaaI apsed 'smell' (<PSaa *epsē- < PU *ipsä-) and SaaN holga SaaI ulgâ 'beam for drying fishing nets on' (< PSaa ${ }^{\star}$ olke $<$ PU *ulki) (UEW: 83-84, 543).

The adjective *ires has no known etymology, but it can be both formally and semantically straightforwardly compared to Pre-Old-Norse *irriar, the expected reflex of PGerm *erzjaz. The word is not attested in Norse, but it is found in other branches of Germanic: Goth airzeis 'deluded, misled, in error', OHGerm irri 'erring, ignorant' (> Germ irre 'mad, confused'), OSax irri 'furious', OEngl eorre 'angry, enraged, furious', OFri ìre 'furious'. The Germanic word is of Indo-European origin and related to Latin errō 'I wander, rove; I go astray, get lost; I err' (Kroonen 2013: 119).

The phonological correspondence between PSaa *ires and the Germanic word is unproblematic, as long as it is assumed that the word was borrowed after the development ${ }^{{ }^{*}} \mathrm{Z}>{ }^{{ }^{*}} \mathrm{r}$ in Norse. PGerm ${ }^{\star}$ erzjaz would first have yielded PNo ${ }^{\star}$ irzjaz by the regular change ${ }^{\star} e{ }^{*}{ }^{*}$ /_C $(C) j$, but Saami *ires can only have been borrowed from some even later development which can be approximately reconstructed as *irriar and which would have eventually yielded ONo ${ }^{*}$ irr, had the word survived in Norse. The substitution of Saami single ${ }^{*}$-r- for Norse geminate ${ }^{*}$-rr- is motivated by a phonotactic constraint, as geminate ${ }^{*}$-rr- seems not to have occurred in Saami at the time of borrowing. In the modern Saami languages one finds very few words that consistently point to an original geminate ${ }^{*}$-rr-, and they are mostly recent borrowings and expressive coinages that show a limited distribution. In some instances the origin of the word remains unknown, but even such cases show a narrow distribution and are thus unlikely to be of Proto-Saami origin (e.g. SaaS vaarredh, SaaU várrat 'run' $<^{*}$ vārre-). As regards the substitution of the PSaa second-syllable vowel ${ }^{*}$-e-for the Norse sequence ${ }^{*}$-ia- $\left(<^{*}\right.$-ja-), this is paralleled by SaaN vuogas 'comfortable, convenient' < vuokẹs from PNo *hōgjaz (> ONo høegr 'easy, convenient') and SaaN vilddas 'wild' < ${ }^{\star}$ viltes $<$ PNo ${ }^{*}$ willpjaz ( $>$ ONo villr 'wild, bewildered, perplexed').

Considering the correspondence between PSaa *ires and PGerm *erzjaz, one might consider it problematic that the Saami sibilant *-s corresponds to the Germanic final ${ }^{*}$ - $z$ of the masculine form, but the correspondence of the medial consonants nevertheless presupposes borrowing after the Norse change ${ }^{\star} \mathrm{Z}>{ }^{*}$. This mismatch is only superficial, however. First, it is not clear that the assimilation ${ }^{\star} \mathrm{rz}>{ }^{*} \mathrm{rr}$ in Norse would have been 
contemporaneous with the general phonological development ${ }^{\star} \mathrm{Z}>{ }^{\star} \mathrm{r}$, as in some consonant clusters $\mathrm{PGerm}{ }^{\star} \mathrm{z}$ has become assimilated to the adjacent consonant before the general rhoticization ${ }^{*} \mathrm{z}>{ }^{*} \mathrm{r}$ (e.g. PGerm ${ }^{*}$-zd- $>$ ONo $-d d$-, PGerm ${ }^{*}$-zn- > ONo -nn-). Second, Saami word-final sibilants are in any event not a reliable criterion for dating borrowings to the Proto-Norse period. It is true that there are numerous Norse loan adjectives in Saami that show a word-final ${ }^{*}$-s corresponding to Germanic masculine forms in * -Z: cf. for example SaaN stuoris 'big' (PNo ${ }^{*}$ stōraz > ONo stórr 'big'), SaaN ruonas 'green (of vegetation)' (PNo *grōniz $>$ ONo grcnn), SaaN ráinnas 'clean' (PNo ^hrainiz > ONo hreinn), as well as SaaN vuogas 'comfortable, convenient' and vilddas 'wild' discussed above. However, the final sibilant also occurs in borrowed adjectives that, on account of their other phonological features, must have been adopted later than the change ${ }^{*} \mathrm{z}>{ }^{*} \mathrm{r}$. A clear example is provided by SaaN eaimmaskas 'stupid, foolish', which on account of its first-syllable vocalism was adopted from a post-umlaut Norse form, either from ONo heimskr 'stupid, foolish' or from its Pre-OldNorse predecessor (?) ${ }^{\star}$ heiməskər, but certainly not from PNo ${ }^{\star}$ haimiskaz (which would instead have yielded SaaN ${ }^{*}(h)$ áimmaskas, or the like).

As a matter of fact, there seem to be no adjectives borrowed from Norse that display a final ${ }^{*}$-r in Saami corresponding to a Norse masculine ending $-r$. Hence, one must conclude that the Norse ending $-r$ could still have been nativized as ${ }^{*}-\mathrm{s}$ in Saami even well after the change of $\mathrm{PNo}{ }^{*} \mathrm{z}$ to ${ }^{*} \mathrm{r}$, despite the fact that $r$ was a completely normal phoneme in Saami, too. This nativization strategy seems to have been motivated by several factors. First, stems ending in ${ }^{*} \mathrm{r}$ were permitted in Proto-Saami, but they seem to have been relatively infrequent and all of them appear to have been nouns; no adjectives of such shape can be reconstructed. Second, the substitution of final ${ }^{*}$-s for Norse $-r$ could have been motivated by the analogy of earlier borrowings, by way of "etymological nativization" (Aikio 2007). Third, the ending ${ }^{*}$-s is a highly frequent adjective suffix in Saami: it forms both deverbal and denominal adjectives (cf. for example SaaN váibbas 'tired' $\leftarrow$ váibat 'get tired', suttis 'unfrozen, not frozen' $\leftarrow$ suddi 'unfrozen spot, opening in ice'), and it also occurs as a secondary suffix marking the predicative form of some adjectives of Uralic origin (e.g. SaaN njuoskkas PRED 'wet' < PU *níčki; SaaN ođas PRED 'new' < PU *wud'i; SaaN goikkis PRED 'dry’ $<$ PU *kuśka-/*kośka-) (UEW: 223, 311, 587). The combination of these three factors made it natural to adopt adjectives borrowed from Norse in a form ending in ${ }^{*}$-s in Saami. 
In semantic terms the etymology is completely straightforward. While none of the attested Germanic forms show exactly the same meaning as the Saami adjective, the correspondence is very close. In the Germanic cognates one can discern two main senses, the first of which is 'deluded misled $\sim$ erring $\sim$ ignorant $\sim$ confused' and the second 'mad $\sim$ angry $\sim$ enraged $\sim$ furious'. Either of these could have easily given rise to 'timid, skittish'. Semantic parallels are provided by SaaN cohcas 'startled, frightened, bewildered; perplexed, confused' and MSax arch 'angry, evil', Sw arg 'angry' ONo argr 'unmanly, cowardly; lewd', OEngl earg 'cowardly, timid' ( $<$ PGerm *arga-; the source of SaaN árgi and Finnish arka 'shy, timid').

2.8. SaaN ivdni, SaaI ivne, SaaSk eu'nn, SaaK iv̄nn, SaaT jǔvinne 'color' $\left(<\mathrm{PSaa}{ }^{*}\right.$ ivnē $)$

$$
<\text { PNo }{ }^{*} \text { ibnī- }\left(<{ }^{*} \text { ebnī- }\right)
$$

PNo ${ }^{\star}$ ibnī- is the expected cognate of OHGerm eban̄ 'level, surface, similarity' ( $<$ PGerm *ebnī-). This form has in itself only a limited attestation in Germanic, but it is derived from the well-attested PGerm adjective *ebna'even, level'; cf. Goth ibns 'even, level, flat', ONo jafn, OEngl efen 'even, equal' (> Engl even), OHGerm eban 'even, equal, straight' (> Germ eben 'level').

In Saami one can postulate a semantic development 'surface' > 'appearance' > 'color'. This is well in line what is in general known of the development of words meaning 'color'. In his discussion of the etymology of Indo-European words for 'color', Buck (1949: 1050-1051) notes that "most of the words for 'color' reflect notions such as 'covering', 'surface, skin', 'countenance, look' or the 'hair' of animals". Examples of this semantic development from Indo-European and Uralic languages include:

- Ancient Greek $\chi \rho$ óa 'skin, surface of the body, skin-color, color'.

- Ancient Greek $\chi \rho \tilde{\omega} \mu \alpha$ 'color (of the skin), make-up, characteristic appearance' > Modern Greek $\chi \rho \omega \dot{\mu} \mu \alpha$ 'color (in general)'.

- Latin color 'color' < *'covering' (cf. the related verb cèlāre 'hide').

- Romanian față 'face, surface; color'.

- Sanskrit varna- 'covering, color' from vr- 'cover'.

- Hungarian szín 'color, appearance, complexion; (archaic:) (upper) surface’.

- Taz Selkup ńüqi ‘surface, cover; tent cover; leather; color’. 
2.9. SaaL muosse 'taste; a bit of food to taste', SaaN muossi 'a bit of food to taste; rest, quiet', SaaI myesi 'rest, quiet' (< PSaa *muosē)

$<$ PNo ${ }^{*}$ mōsa-

The Saami words display rather unusual polysemy. The connection between 'a bit of food to taste' and 'rest, quiet' is not obvious at first sight, but it is possible to postulate an original meaning 'food', which would then have developed to 'a bit to taste' on the one hand and to 'nourishment' > 'rest' (> 'quiet') on the other. This semantic reconstruction is further verified by the discovery of the following loan original: PNo ${ }^{*}$ mōsa- 'food' can be reconstructed as the unattested Nordic cognate of OEngl OFri mōs, MDu moes, OHGerm muos 'food'. The West Germanic words continue PGerm ${ }^{*}$ mōsa- (< ${ }^{*}$ mōssa- $<$ Pre-PGerm ${ }^{*}$ mōd-to-). This word stands in an obscured derivational relationship to another, more widely attested Germanic word for 'food': Goth mats, ONo matr, OHGerm maz, OEngl mete 'food' (> Engl meat) $\left(<\right.$ PGerm ${ }^{\star}$ mati- < Pre-PGerm ${ }^{*}$ modi-) (Kroonen 2013: 358, 372). The formation must be very old, as the derivative has participated in the regular development of a Pre-Proto-Germanic morpheme-boundary cluster ${ }^{*}$-d-tinto *-ss-, which was subsequently degeminated into PGerm * ${ }^{\star}$ s- when preceded by a long vowel. This proves that the West Germanic word * mōsa- is an archaism that once existed also in the predecessor of the Nordic languages.

\subsection{SaaS plaahkoe 'low, flat terrain' (< PSaa * plākkō)}

$<$ PNo ${ }^{*}$ flaka- ${ }^{*}$ flakō-

The South Saami word is quite obviously a borrowing due to its initial consonant cluster $p l$-. I have earlier argued that the word is related to SaaL láhko, SaaN láhku 'wide, flat basin up in the mountains' (< PSaa *lākō) and a borrowing from PNo ${ }^{*}$ flahu- $>$ ONo fló 'rock ledge; gently sloping valley up in the mountains' (Aikio 2012: 111). However, while the SaaL and SaaN words obviously derive from PNo *flahu-, their connection to SaaS plaahkoe $\left(<{ }^{*}\right.$ plākkō) remains problematic as the latter word contains an original geminate stop; the comparison could only be maintained by an ad hoc postulation of an irregular change ${ }^{\star} k>{ }^{*} k k$. Because Saami geminate stops were regularly substituted for Proto-Norse unvoiced stops in intervocalic position, it is preferable to compare SaaS plaahkoe to OHGerm flah (> Germ flach) and MDu vlac (> Du vlak) 'flat' (< PGerm *flaka-). Considering that the Saami word has a rounded vowel in the second syllable, the 
exact loan original could have been $\mathrm{PNo}{ }^{*}$ flakō-, the unattested cognate of OHGerm flahha 'surface; sole (of the foot)', OSax flaka 'sole (of the foot)'. However, as pointed out by Johan Schalin in the Academia.edu discussion session, the Nordic languages do have nouns reflecting the form ${ }^{\star}$ flaka-: cf. for example Swedish flak 'wide, level surface, esp. of a large stretch of open water', Icel flak 'plain'. As these forms suit very well as the loan original except for the minor issue of the second-syllable vowel, it is possible that the source of borrowing is attested in Norse after all.

2.II. SaaS raavtedh 'get strength, become effective (of bark liquor)', SaaN rávdat 'get color and taste by being warmed or boiled up (e.g. coffee, tea)' (< PSaa *rāvtę-)

$<$ PNo *grautē-

The Saami verb can be straightforwardly compared to OHGerm grōzēn 'increase, grow thick, become stronger, swell', OEngl greātian 'become great or large', ge-greātian 'become thick or stout' ( $<{ }^{*}$ grautē-), a verb derived from the PGerm adjective * grauta- $>$ OHGerm grō $z$ ( $>$ Germ groß 'big'), OEngl greeat 'coarse, large, great' (> Engl great). The meaning 'grow thick, become stronger' comes very close to the meaning of the Saami verbs. Note also the etymologically related PNo *grautiz (> ONo grautr 'porridge'), which was the source of SaaS kraavhtse, SaaN (dialectal) rákca 'porridge' (<PSaa ${ }^{*}(\mathrm{k})$ rāvcce $<{ }^{*}(\mathrm{k})$ rāvttess). The word-initial consonant cluster $k r$ - in South Saami indicates that this is a younger borrowing than the verb raavtedh.

2.12. SaaSk raujjeed (rau'jjeed?), SaaK rā̄̄j.ded, SaaT rajvaded 'run, gallop (of draught reindeer)' (< PSaa ${ }^{\star}$ rāvję-tē-) ${ }^{4}$

$<$ PNo *pragja-

The Saami verb is derived with the highly productive verb suffix ${ }^{\star}$-tē- $(<\mathrm{PU}$ ${ }^{*}$-tA-) from a root ${ }^{*}$ rāvje-, which must stem from PNo ${ }^{*}$ pragja-, the unattested Norse counterpart of Goth pragjan and OEngl progan 'run'. The Germanic verb reflects Pre-PGerm ${ }^{\star}$ trog $^{\mathrm{h}}$-eye-, an intensive formation of

4. As pointed out by an anonymous reviewer, the SaaSk form rau'jjeed given in the dictionary by Sammallahti \& Mosnikoff (1991) is probably either a recent secondary development or an erroneous normativization, because the dialectal forms attested by Itkonen (1958: 425) point to the literary standard form raujjeed instead. 
a verb root ${ }^{*}$ treg ${ }^{\mathrm{h}}$ - that is also attested in Ancient Greek $\tau \rho \varepsilon \chi^{\prime} \chi \omega$ 'run'; while the occurrence of a plain and an aspirated stop in the same root violates Proto-Indo-European root structure and the verb is thus likely to be of non-Indo-European origin, the presence of a cognate in Greek still shows that it must predate Proto-Germanic (Kroonen 2013: 544). As regards the substitution of Saami ${ }^{*}$-vj- for the Norse cluster ${ }^{*}$-gj-, this is paralleled by SaaN ávju 'edge (of a blade)' < āvjō < PNo *agjō- (> ONo egg 'edge').

\section{Abbreviations}

$\begin{array}{llll}\text { Du } & \text { Dutch } & \text { PGerm } & \text { Proto-Germanic } \\ \text { Engl } & \text { English } & \text { PNo } & \text { Proto-Norse } \\ \text { Far } & \text { Faroese } & \text { Pre-PGerm } & \text { Pre-Proto-Germanic } \\ \text { Germ } & \text { German } & \text { PSaa } & \text { Proto-Saami } \\ \text { Goth } & \text { Gothic } & \text { PU } & \text { Proto-Uralic } \\ \text { Icel } & \text { Icelandic } & \text { SaaI } & \text { Inari Saami } \\ \text { MDu } & \text { Middle Dutch } & \text { SaaK } & \text { Kildin Saami } \\ \text { MHGerm } & \text { Middle High German } & \text { SaaL } & \text { Lule Saami } \\ \text { MSax } & \text { Middle Saxon } & \text { SaaN } & \text { North Saami } \\ \text { Nw } & \text { Norwegian } & \text { SaaP } & \text { Pite Saami } \\ \text { OEngl } & \text { Old English } & \text { SaaS } & \text { South Saami } \\ \text { OHGerm } & \text { Old High German } & \text { SaaSk } & \text { Skolt Saami } \\ \text { ONo } & \text { Old Norse } & \text { SaaT } & \text { Ter Saami } \\ \text { OSax } & \text { Old Saxon } & \text { SaaU } & \text { Ume Saami } \\ \text { OSw } & \text { Old Swedish } & \text { Sw } & \text { Swedish }\end{array}$

\section{References}

Aikio, ANTE. 2007. Etymological nativization of loanwords: a case study of Saami and Finnish. In Toivonen, Ida \& Nelson, Diane (eds.), Saami linguistics, 17-52. Amsterdam \& Philadelphia: John Benjamins.

Aikio = Luobbal Sámmol Sámmol Ánte (Aikio, Ante). 2012. An essay on Saami ethnolinguistic prehistory. In Grünthal, Riho \& Kallio, Petri (eds.), A linguistic map of prehistoric Northern Europe (Mémoires de la Société FinnoOugrienne 266), 63-117. Helsinki: Finno-Ugrian Society.

BucK, CARL DARLING. 1949. A dictionary of selected synonyms in the principal Indo-European languages: A contribution to the history of ideas. With the cooperation of colleagues and assistants. Chicago \& London: The University of Chicago Press.

DE VRIES, JAN. 1962. Altnordisches etymologisches Wörterbuch. Zweite, verbesserte Auflage. Leiden: E. J. Brill.

Derksen, Rick. 2008. Etymological dictionary of the Slavic inherited lexicon (Leiden Indo-European Etymological Dictionary Series 4). Leiden \& Boston: Brill. 
EES = Metsmägi, Iris \& Sedrik, Meeli \& SoosaAr, Sven-Erik (eds.). 2012. Eesti etümoloogiasõnaraamat. Tallinn: Eesti Keele Sihtasutus.

EWbAhd 5 = LüHr, Rosemarie (ed.). 2014. Etymologisches Wörterbuch des Althochdeutschen, Band 5: iba - luzzilo. Göttingen: Vandenhoeck \& Ruprecht.

ITKONEN, T. I. 1958. Koltan- ja kuolanlapin sanakirja I-II (Lexica Societatis FinnoUgricae 15). Helsinki: Suomalais-Ugrilainen Seura.

Koivulehto, Jorma. 1992. Germanisch-lappische Lehnbeziehungen. In Honti, László \& Hahmo, Sirkka-Liisa \& Hofstra, Tette \& Jastrzebska, Jolanta \& Nikkilä, Osmo (eds.), Finnisch-ugrische Sprachen zwischen dem germanischen und dem slavischen Sprachraum. Vorträge des Symposiums aus Anlaß des 25-jährigen Bestehens der Finnougristik an der Rijksuniversiteit Groningen 13.-15. November 1991, 85-95. Amsterdam \& Atlanta: Brill.

Koivulehto, Jorma. 2003. Frühe Kontakte zwischen Uralisch und Indogermanisch im nordwestindogermanischen Raum. In Bammesberger, Alfred \& Vennemann, Theo (eds.), Languages in prehistoric Europe, 279-317. Heidelberg: Universitätsverlag Winter.

Kroonen, GuUs. 2013. Etymological dictionary of Proto-Germanic (Leiden IndoEuropean Etymological Dictionary Series II). Leiden \& Boston: Brill.

LÄGLOS II = HAнmo, SirkkA-LiISA \& Hofstra, Tette \& Nikкilä, Osmo. 1996. Lexikon der älteren germanischen Lehnwörter in den ostseefinnischen Sprachen, $B d$. II: K-O. Amsterdam \& Atlanta: Rodopi.

Nielsen, KonRad. 1979. Lappisk (samisk) ordbok. 2. opplag. Oslo: Instituttet for sammenlignende kulturforskning.

Pronk-Tiethoff, Saskia Elisabeth. 2012. The Germanic loanwords in ProtoSlavic: origin and accentuation. Leiden: Leiden University Centre for Linguistics (LUCL), Faculty of Humanities, Leiden University.

Qvigstad, J. K. 1893. Nordische Lehnwörter im Lappischen (Christiania Videnskabs-Selskabs Forhandlinger for 1893 No. 1). Christiania: Jacob Dybwad.

Sammalahti, Peкка. 2012. On subglottal pulses. In Hyytiäinen, Tiina \& Jalava, Lotta \& Saarikivi, Janne \& Sandman, Erika (eds.), Per Urales ad Orientem: Iter polyphonicum multilingue. Festskrift tillägnad Juha Janhunen på hans sextioårsdag den 12 februari 2012 (Mémoires de la Société Finno-Ougrienne 264), 359-374. Helsinki: Société Finno-Ougrienne.

Sammallahti, Pekka \& Mosnikoff, Jouni. 1991. Suomi-koltansaame sanakirja. Lää'dd-sää'm sää'nnǩke'rjj. Ohcejohka: Girjegiisá.

SKES = Suomen kielen etymologinen sanakirja (Lexica Societatis Finno-Ugricae XII). Helsinki: Suomalais-Ugrilainen Seura. 1955-1981.

SSA = ItKonen, ERKKi \& KulONEN, Ulla-MAIJA (eds.). 1992-200o. Suomen sanojen alkuperä: Etymologinen sanakirja. Helsinki: Kotimaisten kielten tutkimuskeskus \& Suomalaisen Kirjallisuuden Seura.

UEW = RÉDEI, KÁROLY. 1988-1991. Uralisches Etymologisches Wörterbuch. Budapest: Akadémiai Kiadó.

Wiklund, K. B. 1912. Einige urnordische lehnwörter im lappischen. Finnisch-Ugrische Forschungen 12. 30-37. 